\title{
Nitrogen fertilizer management strategy for oil palm-maize intercropping system in the semi-deciduous forest zone of Ghana
}

\author{
I. DANSO*, E. LARBI, E. ANDOH-MENASH, P. F. RIBEIRO, I.K. ADJARKO \& \\ E. AGYARKO-MINTAH \\ (I.D, E.L, E.A-M \& I.K.A.: CSIR-Oil Palm Research Institute, P.O. Box 74, Kade, \\ Ghana; P.F.R.: CSIR-Crops Research Institute, P.O. Box 3785 Fumesua-Kumasi; \\ E.A-M.: Biotechnology and Nuclear Agriculture Research Institute-Ghana Atomic \\ Energy Commission P. O. Box LG 80 Accra) \\ *Corresponding author's email: danso60@yahoo.com
}

\begin{abstract}
In an attempt to increase yield of maize in oil palm-maize intercropping system, farmers resort to indiscriminate cutting of fronds of palms leading to low yield of oil palm. This study evaluated the impact of different $\mathrm{N}$ fertilizer levels on maize varieties in oil palm-maize intercropping system. The economics of nitrogen application was also studied. The treatments were: T1Sole oil palm, T2-Oil palm+'Omankwa', T3-Oil palm+'Abelehi' and T4-Oil palm+ 'Obatanpa'. The crop associations were superimposed with nitrogen fertilizer levels as sub-treatments at $\mathrm{N} 0-\mathrm{N}_{0}: \mathrm{P}_{60}: \mathrm{K}_{60}, \mathrm{~N} 1-\mathrm{N}_{60}: \mathrm{P}_{60}: \mathrm{K}_{60}$ and $\mathrm{N} 2-\mathrm{N}_{120}: \mathrm{P}_{60}: \mathrm{K}_{60}$ per ha. The experiment was a split plot design with three replications. There was no significant difference $(\mathrm{p}<0.05)$ between maize varieties across seasons for both maize yield and aboveground biomass though 'Omankwa' was promising across seasons and more responsive to nitrogen application. Across the three maize varieties, $\mathrm{N}_{60} \mathrm{P}_{60} \mathrm{~K}_{60}$ was significantly higher $(\mathrm{p}<0.05)$ by $40 \%$ and $17 \%$ for maize yield and aboveground biomass respectively as compared to $\mathrm{N}_{0}: \mathrm{P}_{60}: \mathrm{K}_{60}$. The study recommends $\mathrm{N}_{60} \mathrm{P}_{60} \mathrm{~K}_{60}$ fertilizer level and further states that to improve fertilizer adoption, government should subsidize fertilizer cost for farmers to purchase. The outcome of cost benefit analysis revealed that return per cash invested favored cropping system with $\mathrm{N}_{60}: \mathrm{P}_{60}: \mathrm{K}_{60}$ and season with less water stress.
\end{abstract}

Keywords: Nitrogen; intercropping system; semi-deciduous; water stress; maize varieties Original scientific paper. Received 28 Aug 2019; revised 21 May 2020

\section{Introduction}

The oil palm industry in Ghana has developed over the last three decades into a huge and important industry and is considered as the next important cash crop to Cocoa in Ghana. According to Osei-Amponsah et al. (2018), oil palm small-scale farmers occupy about $80 \%$ of the total cultivated area in Ghana. The large oil palm estates such as Benso Oil Palm Plantation
Limited (BOPP), Twifo Oil Palm Plantations Limited (TOPP) and Ghana Oil Palm Development Company Limited (GOPDC) among others constitute the remaining $20 \%$ in Ghana (MASDA, 2010). The crop is cultivated as a monocrop by the large estates and their affiliated smallholders. The large estates inter-plant the oil palm interrows with cover crops for the purpose of conserving soil moisture, suppress-

Ghana Jnl Agric. Sci. 55 (1), 75 - 86

GJAS is an Open Access Journal and distributed under the terms of the Creative Commons (CC) License [CC BY 4.0] 
ing weed growth and controlling soil erosion as well as improving soil fertility. In spite of the many benefits of the leguminous cover crop, the small scale farmers do not intercropped oil palm with cover crops. This is partly due to lack of immediate economic returns accruing from them. The small-scale farmers instead, intercrop the oil palm with food and other cash crops for three to four years. The standard 8.8 $\mathrm{m}$ triangular spacing used for oil palm provides wide spaces between the young palms. According to a survey by Nuertey et al. (1999), maize is the most common staple crop which is haphazardly intercropped in oil palm in the semi-deciduous forest zone of Ghana. In an attempt to increase the yield of maize, farmers resort to indiscriminate cutting of fronds of palms which reduces it photosynthetic ability leading to delay fruiting. There is lack of published research on the systematic arrangement of maize from oil palm rows to lessen competition for resources between the associations.

Current climate variability and climate change poses additional threat in increasing yield of maize intercropped in oil palm in the region. Climate change and variability will cause increasing mean temperatures in the region and observational evidence has already detected a rise in average temperatures of $1{ }^{\circ} \mathrm{C}$ between 1960 and 1990 (Sandwidi, 2007). Maize cultivars with increased tolerance to heat and drought stress and resistance to pests and diseases are critical for managing climate change and climate variability. Additionally, to overcome low yield of maize related to low soil fertility, it is important for farmers to resort to the use of maize cultivars which can give reasonable yield under low nitrogen conditions. Since there is sufficient genetic variability in maize genotypes for $\mathrm{N}$ uptake and $\mathrm{N}$ use efficiency in Ghana, identifying and use of those genotypes that are more productive under low nitrogen conditions will aid in higher yield stabilization. The challenge is that improved maize cultivars have not been readily adopted by Ghanaian smallholder farmers. In this paper, we argue that in the case of Ghana, Policy Makers have tended to overlook the importance of maize cultivars (local varieties) in adapting to low soil fertility and climate variability/change. This has implications for policy as we engage in food security initiatives.

In order to bridge low yield gap in the two-crop association (maize + oil palm), the evaluation of locally bred maize varieties spatially arranged from oil palm rows with appropriate $\mathrm{N}$ fertilizer levels is relevant. Again, there is lack of research on the interactive effects of local maize varieties, planting seasons and $\mathrm{N}$ levels in oil palm maize intercropping system in the semi-deciduous forest zone of Ghana. This study was undertaken with the hypothesis that, with appropriate $\mathrm{N}$ fertilizer level whiles optimizing $\mathrm{P}$ and $\mathrm{K}$, maize spatially arranged from oil palm rows to lessen competition for resources will increase in yield and that the effect is related to planting season. Information generated from this trial is critical to calibrate and validate the cropping system models for future studies in climate change impact and adaptation studies in the region. The study was therefore designed with an objective to:

1. study the impact of different $\mathrm{N}$ fertilizer levels on different maize cultivars in oil palm-maize intercropping system.

2. undertake economic analysis of different maize cultivars intercropped in oil palm under varying levels of nitrogen in different planting seasons. 


\section{Materials and Methods}

Description of study area

A field experiment was conducted at the Council for Scientific and Industrial Research-Oil Palm Research Institute (CSIROPRI), Kusi in the Denkyembour district in the semi-deciduous forest zone of Ghana (Figure 1). The area lies between latitudes $06^{\circ} .02^{\prime}$ and $06^{\circ} .05^{\prime}$ North and longitudes $00^{\circ} .52^{\prime}$ 'and $00^{\circ} .54^{\prime}$ 'West of Greenwich meridian, with an elevation of $164 \mathrm{~m}$ above sea level in the Eastern Region of Ghana.

The study was carried out on the soils of Nzema series classified as Ferric Acrisols (FAO, 1990) and Typic Hapludult (USDA,
1998). The area is in a zone characterized by relatively high rainfall, which falls in two seasons. The major rainy season occurs from April to July. The minor rainy season begins in September to the end of October/or mid-November. The average annual rainfall is about 1425 $\mathrm{mm}$. Temperatures is generally high and uniform throughout the year. The mean monthly temperatures range from $24-30^{\circ} \mathrm{C}$. The month of July records the lowest mean monthly temperatures of about $24^{\circ} \mathrm{C}$, while March records the highest of $30^{\circ} \mathrm{C}$. Generally, in the wet season relative humidity is high ( $95 \%)$, while it is low (about $40 \%$ ) in the dry season.

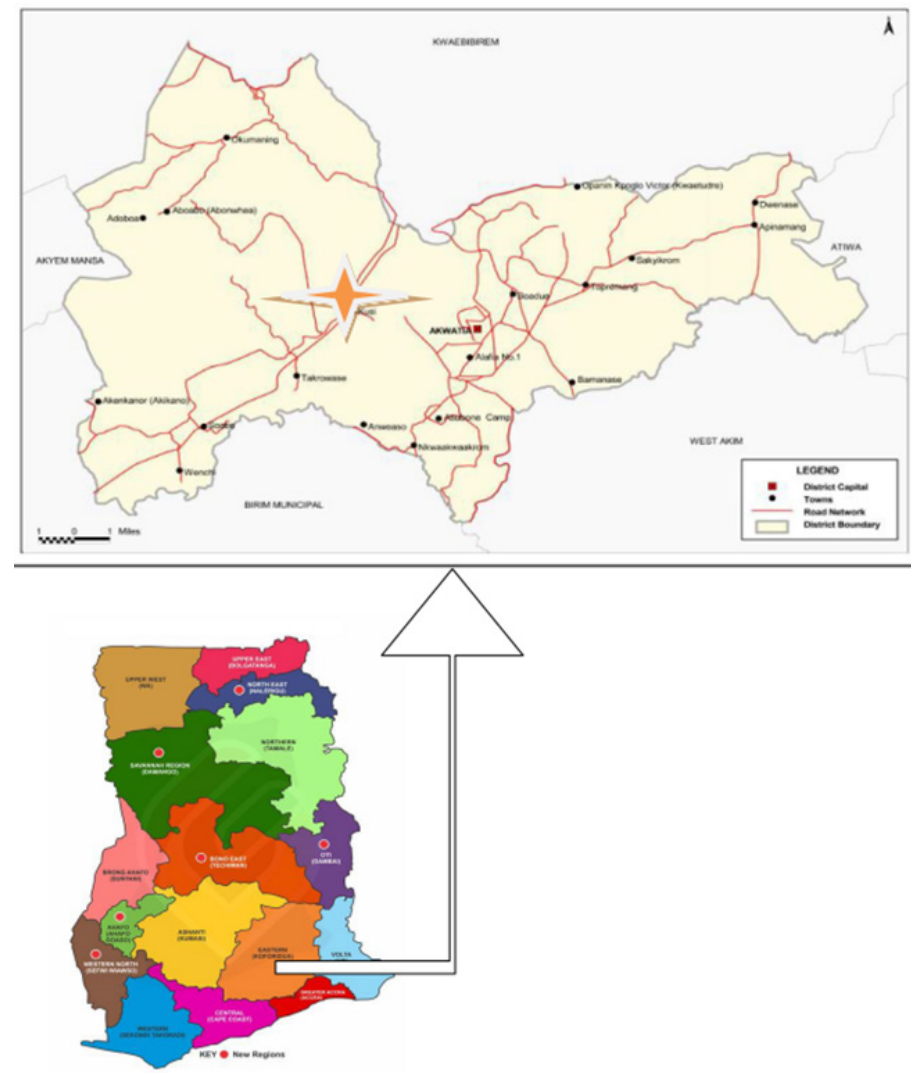

Figure 1: Geographical location of study area (indicated on map with pink star) 
Precipitation regime during the two seasons

The daily weather data were collected from the meteorological station at CSIR-Oil Palm Research Institute. The various precipitation indices including the total amount of rainfall, rainy days, length of longest period without precipitation are shown in Table 1.

TABLE 1

Precipitation from planting to harvest during the two seasons of experiment

\begin{tabular}{lcccc}
\hline Season & $\begin{array}{c}\text { TAR }(m \\
m)\end{array}$ & $\begin{array}{l}\text { Rainy } \\
\text { days }\end{array}$ & $\begin{array}{l}\text { Longest } \\
\text { dry spell } \\
\text { (days) }\end{array}$ & $\begin{array}{l}\text { Month of } \\
\text { longest dry } \\
\text { spell }\end{array}$ \\
\hline $\begin{array}{l}\text { Major } \\
2018\end{array}$ & 729.2 & 40 & 8 & July/Aug. \\
$\begin{array}{l}\text { Minor } \\
2018\end{array}$ & 547.5 & 28 & 28 & Dec./Jan. \\
\hline
\end{tabular}

where TAR is total amount of rainfall

Field experiment

Experimental design and field layout

Following a reconnaissance survey, a suitable site for the experiment was selected. The two seasons experiment was arranged as split plot design with four replications and experimental treatment consisted of three maize varieties 'Obatanpa' (late maturing variety), 'Omankwa' (early maturing variety) and 'Abelehi' (medium maturing variety) intercropped in oil palm (DXP ex OPRI) as main-treatments (Figure 1). The main-treatments were superimposed with three nitrogen fertilizer rates $\left(\mathrm{N} 0-\mathrm{N}_{0} \mathrm{P}_{60} \mathrm{~K}_{60} \mathrm{~kg} \mathrm{ha}^{-1}\right.$, N1-N $\mathrm{P}_{60} \mathrm{~K}_{60} \mathrm{~kg} \mathrm{ha}^{-1}$ and $\mathrm{N} 2-\mathrm{N}_{120} \mathrm{P}_{60} \mathrm{~K}_{60} \mathrm{~kg} \mathrm{ha}^{-1}$ ) as sub-treatments. Each replication had oil palm as a sole crop as an additional main treatment (Figure 2).

\begin{tabular}{|c|c|c|c|c|c|}
\hline \multicolumn{6}{|c|}{ Field layout } \\
\hline \multicolumn{2}{|c|}{ REP I } & \multicolumn{2}{|c|}{ REP II } & \multicolumn{2}{|c|}{ REP III } \\
\hline \multirow{3}{*}{\multicolumn{2}{|c|}{ Sole Oil Palm }} & \multirow{3}{*}{$\mathrm{T}_{3}$} & $\mathrm{~N}_{1}$ & \multirow{3}{*}{$\mathrm{T}_{1}$} & $\mathrm{~N}_{0}$ \\
\hline & & & $\mathrm{N}_{0}$ & & $\mathrm{~N}_{2}$ \\
\hline & & & $\mathrm{N}_{2}$ & & $\mathrm{~N}_{1}$ \\
\hline \multirow{3}{*}{$\mathrm{T}_{2}$} & $\mathrm{~N}_{1}$ & \multirow{3}{*}{$T_{1}$} & $\mathrm{~N}_{1}$ & \multirow{3}{*}{$T_{3}$} & $\mathrm{~N}_{1}$ \\
\hline & $\mathrm{N}_{0}$ & & $\mathrm{~N}_{0}$ & & $\mathrm{~N}_{2}$ \\
\hline & $\mathrm{N}_{2}$ & & $\mathrm{~N}_{2}$ & & $\mathrm{~N}_{0}$ \\
\hline \multirow{3}{*}{$\mathrm{T}_{3}$} & $\mathrm{~N}_{0}$ & \multirow{3}{*}{\multicolumn{2}{|c|}{ Sole Oil Palm }} & \multirow{3}{*}{$\mathrm{T}_{2}$} & $\mathrm{~N}_{2}$ \\
\hline & $\mathrm{N}_{2}$ & & & & $\mathrm{~N}_{1}$ \\
\hline & $\mathrm{N}_{1}$ & & & & $\mathrm{~N}_{0}$ \\
\hline \multirow{3}{*}{$\mathrm{T}_{1}$} & $\mathrm{~N}_{2}$ & \multirow{3}{*}{$\mathrm{T}_{2}$} & $\mathrm{~N}_{0}$ & \multirow{3}{*}{\multicolumn{2}{|c|}{ Sole Oil Palm }} \\
\hline & $\mathrm{N}_{1}$ & & $\mathrm{~N}_{2}$ & & \\
\hline & $\mathrm{N}_{0}$ & & $\mathrm{~N}_{1}$ & & \\
\hline
\end{tabular}

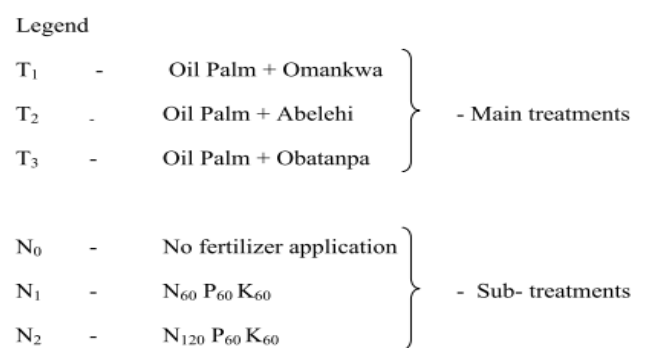

Figure 2: Field layout of experiment

The fertilizers used were urea $(46 \% \mathrm{~N})$, triple super phosphate $\left(46 \% \mathrm{P}_{2} \mathrm{O}_{5}\right)$ and muriate of potash $\left(60 \% \mathrm{~K}_{2} \mathrm{O}\right)$. Fertilizers were broadcast in the plots and worked into the soil immediately to avoid nitrogen volatilization. Optimum $\mathrm{P}$ and $\mathrm{K}$ amounts with $50 \% \mathrm{~N}$ were applied 25 days after planting (DAP) and the remaining $50 \% \mathrm{~N}$ was applied at $45 \mathrm{DAP}$.

Land preparation, planting and crop management

The land was previously cultivated to oil palm and left to go fallow for about 15 years. After clearing, lining and pegging were done and oil palm seedlings were transplanted at a standardized distance of $8.8 \mathrm{~m}$ triangular just at the beginning of the major season rains in 2018. Maize was planted when the soil was moist enough after plots have been sprayed 
with glyphosate (200 ml/ 151 knapsack) to control weeds. The planting and harvesting schedule of maize cultivars is summarized in Table 2. The maize was planted one meter away from oil palm rows and planting density was fixed at 62,500 plants ha ${ }^{-1}$ with $0.8 \mathrm{~m}$ between rows and with two plants per hole at $0.4 \mathrm{~m}$ distance within rows (Figure 3). Maize was protected from fall armyworm invasion with the standard recommendation of 3-4 sprayings with Ema Star 112EC (20 ml per 15 litres) during the maize growing cycle. This was able to keep the fall army worm invasion below their threshold levels in both growing seasons. Plots were kept weed free during the entire growing seasons.

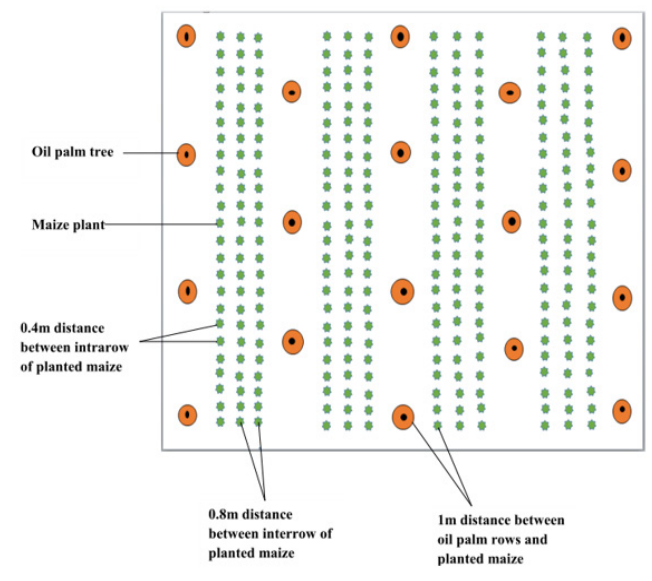

Figure 3: Schematic representation of maize plants arranged 1 meter from oil palm rows

\section{Field measurement of crop parameters}

Measurements taken in the course of the experiment for maize varieties included biomass sampling and plant height at twoweek interval, $50 \%$ days to tasseling, $50 \%$ days to silking and $50 \%$ days to physiological maturity as described by Fosu-Mensah and Mensah (2016). At maturity, yield and yield components of maize cultivars were determined by using the method by Danso et al. (2018). Both vegetative and reproductive information on oil palm is not included in this paper.

\section{Harvest Index (HI)}

Harvest index (HI) was calculated using relation as described by Bange et al., (1998).

Harvest Index $=\frac{\text { Crop yield }}{\text { biomass }}$

Where yield is the economic yield which is seed yield and biomass refers to the total aboveground dry matter at harvest in $\mathrm{kg} \mathrm{ha}^{-1}$.

\section{Soil laboratory analysis}

The Chemical and physical properties of the soil were determined by using the methodology as described by Danso et al. (2018).

\section{Economic analysis}

The cost benefit analysis of N0, N1 and N2 was carried out over the period across seasons and between seasons by comparing production cost of maize cultivars and revenue generated. The total cost $(\mathrm{X})$ of production was calculated as:

$$
\mathrm{X}=\mathrm{a}+\mathrm{b}+\mathrm{c}
$$

where variables $\mathrm{a}, \mathrm{b}$ and $\mathrm{c}$ were: $\mathrm{a}$ : Cost of planting materials, b: Labour cost, and c: Harvesting cost.

The economic yield of maize cultivars for major and minor seasons produced from N0, N1 and N2 during the period of study was multiplied by the price as pertained in the market to estimate the revenue. The cost was deducted from the revenue to indicate whether there was a loss or profit:

$$
\text { Benefit }=\text { Revenue }- \text { Cost }
$$

The cost benefit ratio, which is the return per cash invested (RCI), was calculated by relating revenue generated to total cost of production. This was obtained from the formula: 


$$
\text { Cost benefit ratio }(\mathrm{RCI})=\frac{\text { Revenue generated }}{\text { Total cost of production }}
$$

\section{Statistical analysis}

Dependent variables (maize grain yield, total aboveground biomass, plant height, phenology and harvest index) were subjected to analysis of variance (ANOVA) using a proc mixed analysis procedure engaging the Restricted Maximum Likelihood method with the aid of SAS (version 9.4). Maize cultivars, nitrogen levels and planting seasons were considered as fixed effects. Treatment means were compared by least significant differences (LSD) at $\mathrm{p}<0.05$. Analysis was done by pooling across the two seasons data.

\section{Results}

Physico-chemical properties of the soil prior to application of treatments

The results of the physical and chemical analysis of the soil at the experimental site before imposition of treatments are presented in Table 2. The soil $\mathrm{pH}$ ranged from 4.94 to 5.00. The organic carbon content of the soil is found to be very low $(<1 \%)$. The available phosphorus and CEC are low. The particle size distribution of the soil is found to be $76 \%$ sand, $8 \%$ clay and $16 \%$ silt for soil depth $0-20 \mathrm{~cm}$ and $60 \%$ sand, $14 \%$ silt and $26 \%$ clay for soil depth $20-40 \mathrm{~cm}$. From the results, the texture of the soil is classified as sandy loam for soil depth 0-20 cm and sandy clay loam for 20-40 $\mathrm{cm}$ soil depth. The bulk density was moderately high. There was a general increase in bulk density with increasing depth.
TABLE 2

Chemical and physical properties of soil at experimental site before application of treatments

\begin{tabular}{lll}
\hline Soil Properties & $\begin{array}{l}\text { Soil depth }(\mathrm{cm}) \\
0-20\end{array}$ & $20-40$ \\
\hline Chemical properties & & \\
pH $\left(1: 2.5 \mathrm{H}_{2} \mathrm{O}\right)$ & 5.00 & 4.94 \\
Org. Carbon (\%) & 0.26 & 0.20 \\
Total N (\%) & 0.02 & 0.02 \\
Org. matter (\%) & 0.45 & 0.34 \\
Exchangeable cations & & \\
(cmol/kg) & 1.49 & 1.28 \\
Ca & 1.07 & 0.43 \\
Mg & & \\
K & 0.07 & 0.08 \\
Na & 0.04 & 0.04 \\
T.E.B (cmol/kg) & 2.67 & 1.83 \\
Ex. Acidity (cmol/kg) & 1.10 & 1.20 \\
ECEC (cmol/kg) & 3.77 & 3.03 \\
Base Sat. $(\%)$ & 70.83 & 60.39 \\
Avail. Brays P (ppm) & 1.28 & 1.51 \\
Physical properties & & \\
Sand (\%) & 76.00 & 60.00 \\
Silt (\%) & 8.00 & 14.00 \\
Clay (\%) & 16.00 & 26.00 \\
Texture & Sandy loam & Sandy \\
Bulk density (gm/cm $\left.{ }^{3}\right)$ & 1.15 & Clay \\
& & Loam \\
& & 1.41 \\
\hline
\end{tabular}

Effect of treatments on phenology of maize cultivars intercropped in oil palm

The ANOVA results for main treatment effects and interactions on phenology are summarized in Table 3. During the period of the study, significant difference $(p<0.001)$ was recorded between cultivars and planting seasons for tasseling, silking and physiological maturity. Treatment interaction for planting season and cultivar was significant $(\mathrm{p}<0.001)$ for all the components of phenology. 


\section{TABLE 3}

ANOVA treatment effect on $50 \%$ days to silking, tasseling and physiological maturity of maize varieties during the planting seasons

\begin{tabular}{llllc}
\hline Treatment & D.F & Silking & Tasseling & $\boldsymbol{P M}^{\prime}$ \\
\hline Cultivars & 2 & $* *$ & $* *$ & $* *$ \\
Nitrogen & 2 & $\mathrm{~ns}$ & $\mathrm{~ns}$ & $\mathrm{~ns}$ \\
Season & 1 & $* *$ & $* *$ & $* *$ \\
Cultivar x Nitrogen & 4 & $\mathrm{~ns}$ & $\mathrm{~ns}$ & $\mathrm{~ns}$ \\
Cultivar x Season & 2 & $* *$ & $* *$ & $* *$ \\
Cultivar x Nitrogen x & 4 & $\mathrm{~ns}$ & $\mathrm{~ns}$ & $\mathrm{~ns}$ \\
Season & & & & \\
\hline
\end{tabular}

*Indicates significant at $\mathrm{p}<0.05$

**Indicates significant at $\mathrm{p}<0.01$

'PM - Physiological maturity

Interaction between planting season and maize varieties on phenology

The data pertaining to interactive effect of planting season and maize varieties on phenology is presented in Figure 4-6. During the study, the major season had an average of 6,7 and 9 delay in days to attaining 50\% silking for Abelehi, Obatanpa and Omankwa respectively (Figure 4). The difference in days was significant $(\mathrm{p}<0.01)$ for each maize variety. The interactive effect of $50 \%$ days to tasseling was also significant $(\mathrm{p}<0.05)$ with an average of 5.6 early silking for minor season as compared to major season (Figure 5). The $50 \%$ days to physiological maturity followed a similar trend of delay in maturity for all maize varieties during the major season as compared to minor season (Figure 6).

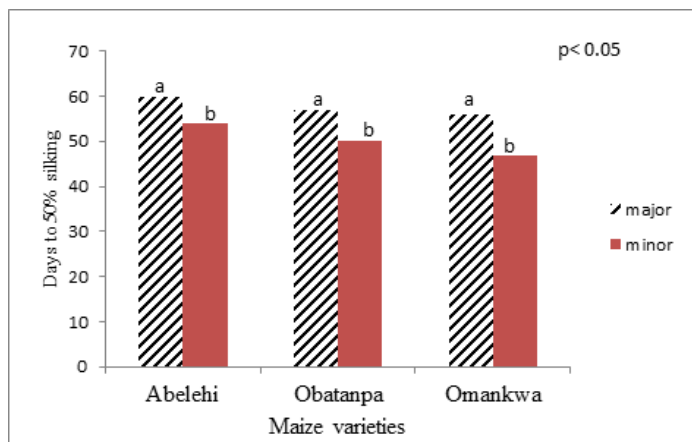

Figure 4: Interactive effect of planting seasons and maize varieties on $50 \%$ days to silking

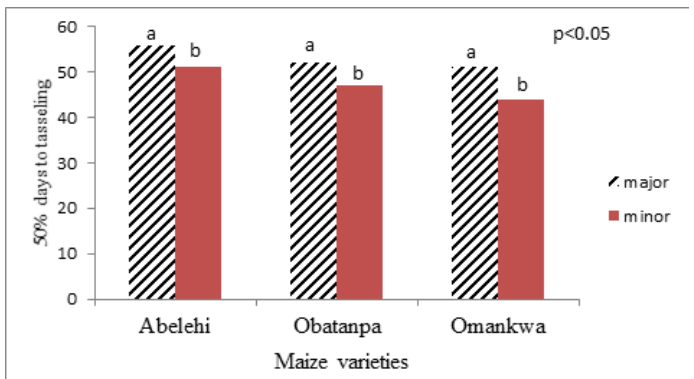

Figure 5: Interactive effect of planting seasons and maize varieties on $50 \%$ days to tasseling

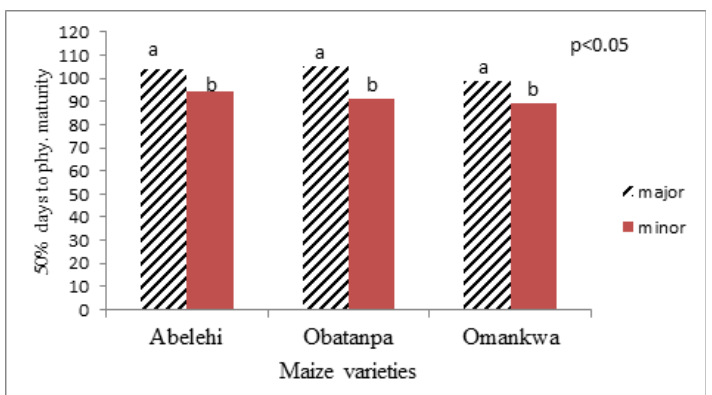

Figure 6: Interactive effect of planting seasons and maize varieties on $50 \%$ days to physiological maturity 
Effect of nitrogen levels on Maize Grain Yield (MGY), Total Aboveground Biomass (TAGB) and Harvest Index (HI) of maize varieties intercropped in oil palm

The ANOVA results for main treatment effects and interactions are summarized in Table 4. No significant difference $(p<0.05)$ was noted between maize varieties. Nitrogen fertilizer levels and planting seasons (major and minor) had a significant effect $(\mathrm{p}<0.05)$ on grain yield (GY), Total Aboveground biomass (TAGB) and Harvest Index (HI). Height was significant $(p<0.05)$ with respect to planting season and cultivars.

TABLE 4

ANOVA showing main treatment effects and interactions on maize grain yield, plant height (HT), total aboveground biomass, and harvest index for maize varieties for both major and minor planting seasons

(Proc. Mixed model)

\begin{tabular}{lllllc}
\hline Treatment & $D . F$ & $G Y$ & $H T$ & TAGB & $H I$ \\
\hline Cultivars & 2 & $\mathrm{~ns}$ & $*$ & $\mathrm{~ns}$ & $\mathrm{~ns}$ \\
Nitrogen & 2 & $* *$ & $\mathrm{~ns}$ & $*$ & $* *$ \\
Season & & & & & \\
Cultivar x Nitrogen & 1 & $* *$ & $*$ & $* *$ & $* *$ \\
Variety x Season & 4 & $\mathrm{~ns}$ & $\mathrm{~ns}$ & $\mathrm{~ns}$ & $\mathrm{~ns}$ \\
Nitrogen x Season & 2 & $\mathrm{~ns}$ & $\mathrm{~ns}$ & $\mathrm{~ns}$ & $\mathrm{~ns}$ \\
Cultivar x Nitrogen x & 2 & $\mathrm{~ns}$ & $\mathrm{~ns}$ & $\mathrm{~ns}$ & $\mathrm{~ns}$ \\
Season & 4 & $\mathrm{~ns}$ & $\mathrm{~ns}$ & $\mathrm{~ns}$ & $\mathrm{~ns}$
\end{tabular}

*Indicates significant at $\mathrm{p}<0.05$

**Indicates significant at $\mathrm{p}<0.01$

As shown in Table 5, maize cultivars planted during the major season had a significantly higher MGY, TAGB and $\mathrm{HI}$ and averaged 54\%, $21 \%$ and $25 \%$ respectively more than those planted during the minor season. Nitrogen application resulted in a significant difference $(p$
$<0.05$ ) between $\mathrm{N}_{60} \mathrm{P}_{60} \mathrm{~K}_{60}$ and $\mathrm{N}_{0} \mathrm{P}_{60} \mathrm{~K}_{60}$ on $\mathrm{GY}$, TAGB and HI. Neither MGY, TAGB nor HI did increase when $\mathrm{N}_{120} \mathrm{P}_{60} \mathrm{~K}_{60}$ was applied relative to $\mathrm{N}_{60} \mathrm{P}_{60} \mathrm{~K}_{60}$. The comparison of means indicated that the maximum harvest index (40\%) was recorded by both $\mathrm{N}_{60} \mathrm{P}_{60} \mathrm{~K}_{60}$ and $\mathrm{N}_{120} \mathrm{P}_{60} \mathrm{~K}_{60}$ as compared to control $\left(\mathrm{N}_{0} \mathrm{P}_{60} \mathrm{~K}_{60}\right)$ with $30 \%$.

TABLE 5

Main effects of maize cultivars, planting season and nitrogen levels on maize grain yield $\left(\mathrm{kg} \mathrm{ha}^{-1}\right)$, total aboveground biomass $\left(\mathrm{kg} \mathrm{ha}^{-1}\right)$ and harvest index

\begin{tabular}{lccc}
\hline Treatment & $M G Y$ & $T A G B$ & $H I$ \\
\hline Variety & & & \\
Omankwa & $4.2 \mathrm{a}$ & $10,369 \mathrm{a}$ & $0.4 \mathrm{a}$ \\
Obatanpa & $3.9 \mathrm{a}$ & $8569 \mathrm{a}$ & $0.4 \mathrm{a}$ \\
Abelehi & $3.6 \mathrm{a}$ & $9162 \mathrm{a}$ & $0.4 \mathrm{a}$ \\
Season & & & \\
Major & $5280 \mathrm{a}$ & $10273 \mathrm{a}$ & $0.5 \mathrm{a}$ \\
Minor & $3410 \mathrm{~b}$ & $8460 \mathrm{~b}$ & $0.4 \mathrm{~b}$ \\
Nitrogen & & & \\
N0 & $3061 \mathrm{a}$ & $8199 \mathrm{a}$ & $0.3 \mathrm{a}$ \\
N1 & $4382 \mathrm{~b}$ & $9605 \mathrm{~b}$ & $0.4 \mathrm{~b}$ \\
N2 & $4420 \mathrm{~b}$ & $10296 \mathrm{~b}$ & $0.4 \mathrm{~b}$ \\
& & & \\
\hline
\end{tabular}

$\mathrm{N} 0=$ zero nitrogen, $\mathrm{N} 1=$ recommended nitrogen, $\mathrm{N} 2=$ high nitrogen. Numbers followed by the same letter in a column were not statistically different at $\mathrm{p}<0.05$.

Interaction between planting season and maize varieties on phenology

The interactive effect of planting season and maize varieties on plant height is presented in Figure 7 . The interaction was not significant $(p<0.05)$. The major planting season recorded significantly higher $(\mathrm{p}<0.01)$ plant height of about $19 \%$ over minor planting season across maize varieties 


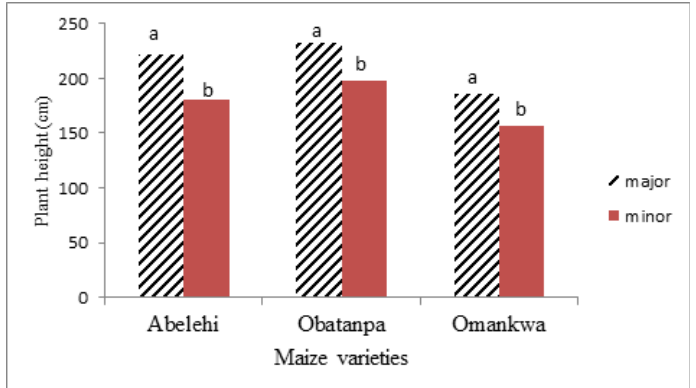

Figure 7: Interactive effect of planting seasons and maize varieties on plant height
Economic analysis

The maize yield information used in the economic analysis is shown in Table 6 whiles revenue and total benefits are presented in Table 7 . The return per cash invested is higher for the major season planting compared to minor season. In a decreasing order of RCI, N0 $<$ N2 $<\mathrm{N} 1$.

TABLE 6

Yield of maize during the planting seasons

\begin{tabular}{lccc} 
& \multicolumn{3}{c}{ Yield $\left(\boldsymbol{t} \boldsymbol{h a}^{-1}\right)$} \\
Season & N0 & N1 & N2 \\
\hline Major & 3.1 & 5.5 & 5.8 \\
\hline Minor & 1.6 & 3.2 & 2.9 \\
\hline
\end{tabular}

TABLE 7

Economic analysis of maize yield as influenced by $N$ fertilizer levels during the two growing seasons

\begin{tabular}{|c|c|c|c|c|c|c|c|c|c|}
\hline \multicolumn{4}{|c|}{ Cost of production (CP) (\$) } & \multicolumn{3}{|c|}{ Revenue (R) (\$) } & \multicolumn{2}{|c|}{$R C I(R / C P)$} & \multirow[b]{2}{*}{ N2 } \\
\hline Season & No & N1 & N2 & No & N1 & $\mathrm{N} 2$ & No & N1 & \\
\hline Major & 313.6 & 435 & 517.2 & 1055 & 1873 & 2009 & 3.3 & 4.3 & 3.9 \\
\hline Minor & 313.6 & 435 & 517.2 & 544 & 1089 & 987 & 0.58 & 2.5 & 1.9 \\
\hline
\end{tabular}

\section{Discussion}

The soil in the study area was strongly acidic with $\mathrm{pH}$ values of 5.0 and 4.9 for $0-20 \mathrm{~cm}$ and $20-40 \mathrm{~cm}$ respectively. The strong leaching of the basic cations out of the top soil contributed to low $\mathrm{pH}$ values of the soil. The organic carbon content was very low $(<1 \%)$ and this may be attributed to continuous cropping of the oil palm site. The low organic carbon content and the exchangeable bases show the highly weathered soils in the humid rainforest agro-ecological zone (Owusu-Bennoah et al., 2000). The low total $\mathrm{N}$ observed is an indication that the nutrient is a limiting factor for optimum crop production and $\mathrm{N}$ response is expected. The low CEC also indicates that soils have poor capacity to retain cations. There was a general increase in bulk density with increasing depth. This trend agrees with the findings of Arshad et al. (1996) that bulk density increases with depths in soil profile.

The increase in grain yield and biomass response observed with the application of nitrogen fertilizer more especially at $\mathrm{N}_{60} \mathrm{~K}_{60} \mathrm{P}_{60}$ indicates how $\mathrm{N}$ is highly deficient in semi-deciduous forest zone soils in Ghana. Under similar conditions, Younas et al. (2002) reported that nitrogen application enhanced grain yield 
on account of increased number of grains per cob. The physiological efficiency and ability of maize varieties to convert the total dry matter into economic yield (harvest Index) favored plots that received $\mathrm{N}$ fertilizers. Lawrence et al. (2008) and Zeidan et al. (2006) reported that the harvest index in corn increases when $\mathrm{N}$ rates increase. The results are further corroborated by Bange et al. (1998) who observed better accumulation and redistribution of assimilates for $\mathrm{N}$ fertilized plots relative to non-fertilized plots.

According to Hay and Gilbert (2001), harvest index of maize has been reported to be 0.5 for most tropical maize crops. However, in our experiment the harvest index values recorded were below this value and this may be due to late sowing and erratic rainfall conditions more especially during critical growth stage of the crop (Ahmad et al., 2007).

Under high and even distribution of rainfall (major season) maize plant used more assimilates for sink formation instead of building the source. Generally, the study has revealed high variability in maize biological yields between major and minor seasons. The rainfall information at the experimental site revealed a higher and even distribution of rainfall during the major season as compared to the minor season. These findings appear to corroborate the views of Adejuwon (2005) that variability in climate/rainfall had wide impacts on maize yields in the southern part of Nigeria. The work revealed that the more the rainfall variability, the less reliable the maize yields. These findings are also explained by Thornton et al. (2009) in a study on spatial variation of crop yield responses to climate variability in East Africa region where they reported low maize yield during seasons with intense dry spells. Our results in the minor season validat- ed the statement that water stress during certain seasons is a widespread phenomenon in West Africa and according to Heisey and Edmeades, (1999) there is about 25\% yield loss of crops annually. Substantial gains in yield registered during the major season may be attributed to increased vegetative phase of maize as evident in maize phenology in this study. This led to more solar radiation interception during the life cycle of maize resulting in higher biomass accumulation.

The economic analysis indicated that major season planting of maize in oil palm is more promising than minor season in the semi-deciduous forest zone of Ghana and return per cash invested were greater for major season regardless of the level of nitrogen fertilizer applied. Investing with $\mathrm{N}_{60} \mathrm{P}_{60} \mathrm{~K}_{60}$ per ha fertilizer levels for both seasons was found to be more beneficial for farmers with a low risk of financial failure. Cost benefit analysis equally favored season with adequate amount and even distribution of rainfall. Thus, farmers have to put in place moisture conservation measures to reverse the risk of crop failure when dry spells are expected.

\section{Conclusion}

The amount of precipitation and its distribution is one major factor that was found to have impact on the system. Our analysis suggests that the changes in precipitation patterns between the two seasons influenced maize yield to a greater extent. Dry spells had an inverse relationship with harvest index of maize. The outcome of cost benefit analysis revealed that return per cash invested favored cropping system with $\mathrm{N}_{60} \mathrm{P}_{60} \mathrm{~K}_{60}$ fertilizer levels and season with relatively high amount of rainfall and evenly distribution. The study, therefore, recommends $\mathrm{N}_{60} \mathrm{P}_{60} \mathrm{~K}_{60}$ fertilizer level and further states that 
in order to improve the rate of fertilizer adoption, the government should subsidize the cost of fertilizer in order to make it affordable for farmers to purchase to increase crop productivity. Data generated will serve as a platform for calibration and validation of maize CERES crop growth simulation model (DSSAT $\mathrm{V}$ 4.7.5) for future climate change impact and adaptation studies for oil palm-maize cropping systems in the region.

\section{Acknowledgement}

This work which served as a platform for the generation of field data for calibration of DSSAT Model (V4.7.5) was funded by the Council for Scientific and Industrial Research Competitive Research Grant Scheme (CRGS) under the contract number 005 . The services of the technical staff of the Agronomy Division of CSIR-OPRI and the monitoring and the evaluation team of this project at CSIR Head office are therefore acknowledged. This paper is published with the permission of the Ag. Director of CSIR-OPRI.

\section{REFERENCES}

Adediran, J.A. \& Banjoko, V.A. (1995) Response of Maize to Nitrogen, Phosphorus and Potassium fertilizers in the savanna zone of Nigeria. Communications in Soil Science and Plant Analysis 26, 593 - 606 .

Adejuwon, J.O. (2005) Food crop production in Nigeria: Present effects of climate variability. Climate Research, Inter-Research, Germany 30, $53-60$.

Ahmad, R., Hassan, B. \& Jabran, K. (2007) Improving crop harvest index. Ramazan 18, 1428. Daw. Gr. Newspapers. http://www.DAWN. com

Amanullah, K.H., Riaz, A. \& Khalil, S.H. (2010) Plant density and nitrogen effects on maize phenology and grain yield. Journal of Plant Nutrition 32 (2), 246 - 60.

Osei-Amponsah, C., Agbotse, P, Swanzy F. \& Stomph T. J. (2018) Role of small-scale enterprises in agricultural development agendas: Insights from oil palm processing enterprises in the Kwaebibirem District of Ghana. Ghana Journal of Agricultural Science 52, $131-144$.

Arsha, M. A., Lowery, B. \& Grossman, B. (1996) Physical tests for monitoring soil quality. In J. W. Doran, and A. J. Jones (Eds.), Methods for AssessingSoil Quality, 123 - 142. Madison, Wis, Soil Science Society of America.

Bange, M.P.,Hammer, G.L. \& Rickert, K.G. (1998) Temperature and sowingdate affect the linear increase of sunflower harvest index. Agronomy Journal 90, 324 - 328.

Bray, R.H. \& Kurtz, L.T. (1945) Determination of total, organic and available forms of phosphorus in soil. Soil Science 599, $39-45$.

Bouyoucos, G.J. (1962) Hydrometer method improved for making particle sizeanalysis of soils. Agronomy Journal 54, 464 - 465.

Danso, I., Webber, H., Bourgault, M., Ewert, F., Naab, J.B. \& Gaiser, T., (2018b) Crop management adaptations to improve and stabilize crop yields under low-yielding conditions in the Sudan Savanna of West Africa. European Journal of Agronomy 101, 1 - 9. https://doi. org/10.1016/J.EJA.2018.08.001.

FAO, (1990) Soil Map of the World- Revised Len gend, $4^{\text {th }}$ Draft. FAO. Rome.

Fosu-Mensah, B.Y. \& Mensah, M. (2016) The effect of phosphorus and nitrogen fertilizers on grain yield, nutrient uptake and use efficiency of two maize (Zea mays L.) varieties under rain fed condition on Haplic Lixisol in the forestsavannah transition zone of Ghana. Environmental System Research 5, pp. 22 https//doi 10.1186/s4006801600732. 
Hay, R.K.M. \& Gilbert, R.A. (2001) Variability in the harvest index of tropical maize: evaluation of recent evidence from Mexico and Malawi. Annual Applied Biology 138, 103 - 109. doi:10.1111/j.17447348.

Heisey, P.W. \& Edmeades, G.O. (1999) World maize facts and Trends 1997/98.CYMMT, Mexico City, Mexico.

Lawrence, J.R., Ketterings Q.M. \& Cherney J.H. (2008) Effect of nitrogen application on yield and quality of corn. Agronomy Journal $\mathbf{1 0 0}$ (1), $73-9$.

MASDAR, (2010). Ghana's Oil Palm Master Plan Final Report. Ministry of Food and Agriculture (MOFA).

Nelson, D. W. \& Sommers, L.W. (1982) Total carbon, organic carbon and organic matter, In: Page, A.L., R.H. Miller. \& D.R. Keeney. (eds.). Methods of Soil Analysis. 2. Chemical and Microbiological Properties. Agronomy 9, 301 -312 .

Nuertey, B.N. (1999) Studies on oil palm based cropping systems in Ghana. Ph.D Thesis. University of Ghana, Crop Science Department.
Owusu-Bennoah, E., Fardeau, J.C. \& Zapata, F. (2000) Evaluation of bio-available phosphorus in some acid soils of Ghana using ${ }^{32} \mathrm{P}$ isotopic exchange method in Ghana Journal of Science 33, $139-146$.

Sandwidi, W.J.P. (2007) Groundwater potential to supply population demand within the Kompienga dam basin in Burkina Faso. PhD Thesis. Ecology and Development Series, No. 54. Cuvillier Verlag Göttingen. pp. 160.

Thornton, P.K., Jones P.G., Gopal, A. \& Andresen, J. (2009) Spatial crop yield response to climate change in East Africa. Global Environmental Change 19, $54-65$.

USDA, (1998) Year Book of Agriculture, Washington.

Younas, M., Rehman, H. \& Hayder, G. (2002) Magnitude of variability for yield and yield associated traits in maize hybrids. Asian Journal of Plant Science 1, $694-696$.

Zeidan, M.S., Amany A. \& El-Kramany, M.F. (2006) Effect of N-fertilizer and plant density on yield and quality of maize in sandy soil. Research Journal of Agriculture and Biological Science 2 (4), 156 - 6. 